\title{
Steel Fibres: Effective Way to Prevent Failure of the Concrete Bonded with FRP Sheets
}

\author{
V. Gribniak, ${ }^{1}$ A. K. Arnautov, ${ }^{2}$ A. Norkus, ${ }^{3}$ R. Kliukas, ${ }^{4}$ V. Tamulenas, ${ }^{5}$ \\ E. Gudonis, ${ }^{5}$ and A. Sokolov ${ }^{1}$
}

${ }^{1}$ Research Laboratory of Innovative Building Structures, Vilnius Gediminas Technical University (VGTU), LT-10223 Vilnius, Lithuania

${ }^{2}$ Institute of Polymer Mechanics, University of Latvia, Riga LV-1006, Latvia

${ }^{3}$ Department of Geotechnical Engineering, VGTU, LT-10223 Vilnius, Lithuania

${ }^{4}$ Department of Strength of Materials and Engineering Mechanics, VGTU, LT-10223 Vilnius, Lithuania

${ }^{5}$ Department of Bridges and Special Structures, VGTU, LT-10223 Vilnius, Lithuania

Correspondence should be addressed to V. Gribniak; viktor.gribniak@vgtu.lt

Received 14 April 2016; Revised 31 October 2016; Accepted 20 November 2016

Academic Editor: Paolo Ferro

Copyright (c) 2016 V. Gribniak et al. This is an open access article distributed under the Creative Commons Attribution License, which permits unrestricted use, distribution, and reproduction in any medium, provided the original work is properly cited.

\begin{abstract}
Although the efficiency of steel fibres for improving mechanical properties (cracking resistance and failure toughness) of the concrete has been broadly discussed in the literature, the number of studies dedicated to the fibre effect on structural behaviour of the externally bonded elements is limited. This experimental study investigates the influence of steel fibres on the failure character of concrete elements strengthened with external carbon fibre reinforced polymer sheets. The elements were subjected to different loading conditions. The test data of four ties and eight beams are presented. Different materials were used for the internal bar reinforcement: in addition to the conventional steel, high-grade steel and glass fibre reinforced polymer bars were also considered. The experimental results indicated that the fibres, by significantly increasing the cracking resistance, alter the failure character from splitting of the concrete to the bond loss of the external sheets and thus noticeably increase the load bearing capacity of the elements.
\end{abstract}

\section{Introduction}

An increasing decay of the civil engineering infrastructure and arising design requirements (e.g., increased traffic exceeding the initial design loads) have received considerable attention in recent years throughout the world. For the purpose of structural rehabilitation, fibre reinforced polymer (FRP) composites have become a promising alternative to conventional techniques, which use steel components together with high performance concrete [1-4]. FRP has gained recognition against the traditional structural materials, due to its exceptional properties, like high tensile strength, corrosion resistance, and durability, as well as reduced time of construction, easy handling, and transportation [5].

In the current engineering practice, reinforced concrete (RC) is the most widely used structural material [6]. However, the brittleness of concrete and low corrosion resistance of the conventional steel reinforcement are generally the key causes of deterioration of buildings. Although some FRP (e.g., glass or basalt polymers) are defined by a relatively low deformation modulus, they can be effective at controlling the development of cracks when used as an additional external reinforcement [7].

The increased stiffness of externally bonded components (sheets, plates, laminates, etc.) introduces additional failure options into the behaviour of structural components such as the brittle loss of the bond at the FRP-to-concrete interface [8-11] or the rip-off of the concrete [12, 13]. Experimental works $[14,15]$ revealed that the addition of steel fibres is an efficient means for preventing the rip-off failure of the concrete. Furthermore, fibres enhance the durability and reduce the cost of maintenance as they limit severe degradation [16, 17]. Although the repair and strengthening of RC structures are the main field of application of advanced FRP materials, the development of new structural systems, for example, hybrid bridge structures with steel fibre reinforced concrete (SFRC) decks adhesively bonded with FRP girders, reflects a great potential for further applications [18-20]. 
The efficiency of steel fibres at improving mechanical properties (cracking resistance and failure toughness) of the concrete has been broadly discussed in the literature, for example, [21-26]. However, the number of studies dedicated to the fibre effect on the structural behaviour of the externally bonded elements is limited. In this context, the aforementioned studies $[14,15]$ should be appreciated as valuable contributions.

This experimental study investigates the influence of steel fibres on the failure character of concrete elements covered with external carbon fibre reinforced polymer sheets. The elements were subjected to different loading conditions. Different materials were used for the internal bar reinforcement. The experimental program is comprised of two parts. The first part deals with concrete ties reinforced with high-strength steel bars. The second part considers the structural behaviour of concrete beams reinforced with steel or glass FRP (GFRP) bars in the tensile zone. The test data of four ties and eight beams are presented further in the paper.

\section{Specimens and Testing Procedures}

The effectiveness of the fibres at transferring the tensile stresses through the crack (the so-called residual strength of the fibre reinforced concrete) depends on the considered deformation (crack opening) state [27]. Thus, the present experimental program concerns different types of reinforcement bars in order to ensure versatility of the findings. The ties were reinforced with high-strength (At800) bars to account for the specific layout of the tensile tests (i.e., the load applied directly to the reinforcement). As a result, the experimental analysis of the fibre effect covers a wider deformation range. For the same reason, GFRP bars were introduced for consideration during the beam tests: the lower elasticity modulus of the polymer bars noticeably increases the monitored deformations in the tensile zone. Similar effects can be observed in the beams reinforced with steel bars (S500) after yielding of the tensile reinforcement.

Unidirectional carbon fibre reinforced polymer (CFRP) sheets MapeWrap C UNI-AX with a weight-per-area ratio of $300 \mathrm{~g} / \mathrm{m}^{2}$ (the equivalent thickness of dry fabric is $0.166 \mathrm{~mm}$ ) were used for the strengthening. An epoxy primer and putty for levelling the concrete surface were applied in order to ensure the bond strength of the concrete-to-CFRP interface. The wet lay-up system was used for the external CFRP reinforcement. The CFRP sheets were glued to the surface using a two-component epoxy resin (MapeWrap 31). The epoxy resin was allowed to cure for 7 days before testing. Three samples of each type of reinforcement bars were tested. The strength and modulus of elasticity are based on nominal diameters. Yield strength of $\varnothing 6$ and $\varnothing 8 \mathrm{~mm}$ (steel S500) and conventional yield strength of $\varnothing 14 \mathrm{~mm}$ bars (steel At800) were 565, 545, and $945 \mathrm{MPa}$, respectively; elastic moduli of the bars were, respectively, equal to 209, 203, and $194 \mathrm{GPa}$ for $\varnothing 6, \varnothing 8$, and $\varnothing 14 \mathrm{~mm}$ steel bars and $64.7 \mathrm{GPa}$ for the $\varnothing 8 \mathrm{~mm}$ GFRP bar. The tensile strength and modulus of elasticity of CFRP sheets were $4830 \mathrm{MPa}$ and $230 \mathrm{GPa}$, respectively.

Concrete compositions (Mixes I-IV) are presented in Table 1. Ordinary Portland cement and crushed granite aggregate (16 mm maximum nominal size) were used. The hooked end steel fibres from two suppliers, that is, Duoloc and Mechel Nemunas, were used for the ties and beams, respectively. The main parameters of the fibres are presented in Table 2. All specimens were cast using steel formwork and unmoulded in about 2-3 days after the casting. The ties were cured in the water tank at the temperature of 18$20^{\circ} \mathrm{C}$, while the beams were stored in the laboratory with an average relative humidity (RH) of $55.5 \%$ and temperature $21.1^{\circ} \mathrm{C}$. Specimen types are described in Table 1.

2.1. Tie Test. The first part of the experimental investigation involves four RC ties of $1000 \mathrm{~mm}$ in length with a $100 \times$ $100 \mathrm{~mm}$ cross section: two reference specimens (T3-Ref-F0 and T4-Ref-F0.6) and two ties externally bonded with CFRP sheets. The specimens were grouped into two series. The ties of the first series (T1-C3-F0 and T3-Ref-F0) were made of ordinary concrete, whereas the ties of the second series (T2C1-F0.6 and T4-Ref-F0.6) had a 0.6\% steel fibre content by volume of concrete. Deformed bars of high-strength At 800 steel were used as the internal reinforcement of $\mathrm{RC}$ ties. The layers of carbon fibres were attached on two opposite sides along the entire length of the concrete (Figure 2(a)). Specimens strengthened with one (T2-C1-F0.6) and with three (T1-C3-F0) layers of CFRP sheets were produced. The main parameters of the ties are listed in Table 1 . In the notation, the first letter refers to the type of specimen ( $T$ " = tie, " $B$ " = beam), whereas the first number corresponds to the sample's number, the abbreviation " $\mathrm{nm}$ " (if applicable) corresponds to a "nonmetallic" tensile reinforcement, the second notation component refers to the existence of the external CFRP reinforcement ("Ref" = unbonded reference, "Cl" = one layer, and "C3" = three layers of CFRP sheets), and the last notation component corresponds to the presence of fibres in the concrete ("FO" = plain concrete, " $F 0.6$ " $=0.6 \%$ volume fraction, and "F0.8" $=0.8 \%$ volume fraction of steel fibres).

The ties were tested by applying the load to the steel bar axially placed in the concrete prism using a displacementcontrolled servohydraulic machine with $600 \mathrm{kN}$ capacity. The loading rate was $0.1 \mathrm{~mm} / \mathrm{min}$. The load was measured with the electronic load cell of the testing machine. Linear variable displacement transducers (LVDT, Figures 1 and 2), attached to the bar, surface of the concrete, and the CFRP sheets, were used for recording deformations. As shown in Figure 2, the slip of a CFRP sheet was monitored using two additional LVDT attached to the concrete edge and CFRP surface in the boundary zone. The crack development was observed and recorded using a 50 magnification (50x) optical microscope. The test was terminated after failure of the concrete or after reaching the ultimate stress in the reinforcement bar.

2.2. Beam Test. The second part of the program consists of eight rectangular section RC beams with a nominal length of $1500 \mathrm{~mm}$ (span $1240 \mathrm{~mm}$ ). Three reference specimens (B3Ref-F0.8, B4-Ref-F0.8, and B7-nm-Ref-F0) were unstrengthened, whereas the remaining five beams were strengthened with one layer of CFRP sheet by applying it on the bottom side. The specimens were classified into two series. The beams 
TABLE 1: Main characteristics and mix proportions of the experimental specimens.

\begin{tabular}{|c|c|c|c|c|}
\hline \multirow{2}{*}{$\begin{array}{l}\text { Specimens } \\
\text { Series }\end{array}$} & \multicolumn{2}{|c|}{ Ties } & \multicolumn{2}{|c|}{ Beams } \\
\hline & I & II & I & II \\
\hline Notation & $\begin{array}{l}\text { T1-C3-F0; } \\
\text { T3-Ref-F0 }\end{array}$ & $\begin{array}{l}\text { T2-C1-F0.6; } \\
\text { T4-Ref-F0.6 }\end{array}$ & $\begin{array}{l}\text { B1-nm-C1-F0; } \\
\text { B7-nm-Ref-F0; } \\
\text { B8-C1-F0 }\end{array}$ & $\begin{array}{c}\text { B2-nm-C1-F0.8; } \\
\text { B3-Ref-F0.8; } \\
\text { B4-Ref-F0.8; } \\
\text { B5-C1-F0.8; } \\
\text { B6-C1-F0.8 }\end{array}$ \\
\hline Tensile bar reinforcement & \multicolumn{2}{|c|}{$1 \times \varnothing 14$, steel At800 } & \multicolumn{2}{|c|}{$2 \times \varnothing 8$, steel S500 or GFRP } \\
\hline Concrete & Mix I & Mix II & Mix III & Mix IV \\
\hline Age at the testing, days & $124 ; 107$ & $131 ; 117$ & $1377-1431$ & $1442-1472$ \\
\hline Compressive strength, $\mathrm{MPa}$ & 55.1 & 50.0 & 50.6 & 31.6 \\
\hline \multicolumn{5}{|l|}{ Mixture proportions, $\mathrm{kg} / \mathrm{m}^{3}$ : } \\
\hline Sand $0 / 4 \mathrm{~mm}$ & $885 \pm 1 \%$ & $885 \pm 1 \%$ & $910 \pm 2 \%$ & $905 \pm 2 \%$ \\
\hline Crushed aggregate $5 / 8 \mathrm{~mm}$ & \multirow{2}{*}{$975 \pm 2 \%$} & \multirow{2}{*}{$975 \pm 2 \%$} & $389 \pm 2 \%$ & $388 \pm 1 \%$ \\
\hline Crushed aggregate $11 / 16 \mathrm{~mm}$ & & & $551 \pm 2 \%$ & $548 \pm 1 \%$ \\
\hline Cement CEM I $42.5 \mathrm{~N}$ & $380 \pm 0.5 \%$ & $380 \pm 0.5 \%$ & $415 \pm 1 \%$ & $400 \pm 0.5 \%$ \\
\hline Water & $160 \pm 3 \%$ & $160 \pm 3 \%$ & $174 \pm 5 \%$ & $124 \pm 5 \%$ \\
\hline Concrete plasticizer & \multicolumn{2}{|c|}{$\begin{array}{c}1.7 \pm 2 \% \\
\text { MC-PowerFlow } 1124\end{array}$} & $\begin{array}{c}3.3 \pm 2 \% \\
\text { Stachement } 2067\end{array}$ & $\begin{array}{c}2.0 \pm 2 \%, \\
\text { Muraplast FK } \\
63.30\end{array}$ \\
\hline Fibres & - & $45 \pm 5 \%$, Duoloc & - & $\begin{array}{c}60 \pm 5 \% \\
\text { MECHEL } \\
\text { NEMUNAS }\end{array}$ \\
\hline
\end{tabular}
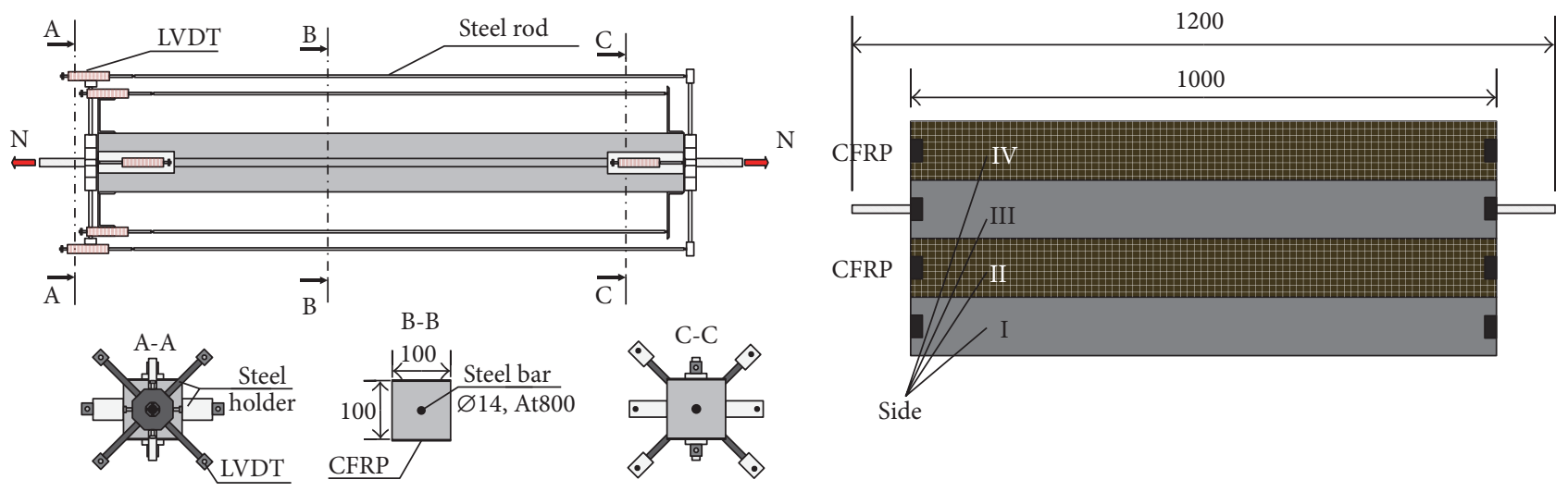

FIgURE 1: Tie test setup.

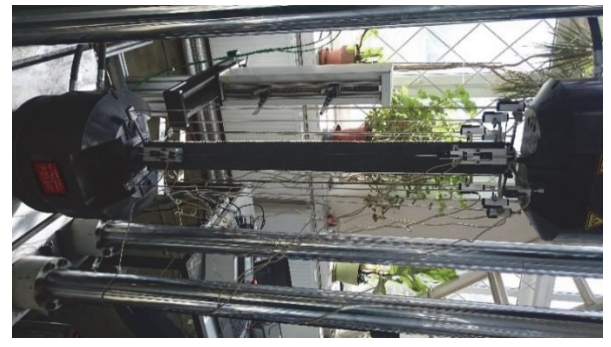

(a)

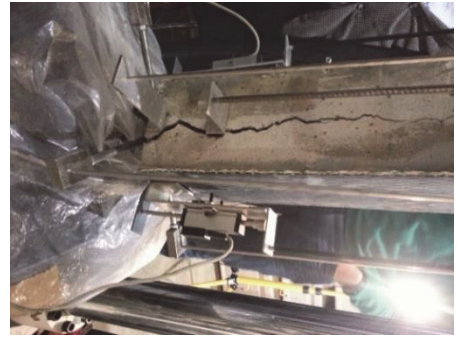

(b)

FIGURE 2: Tensile test (a) and zoomed view of LVDT for monitoring slip of the CFRP sheet (b). 

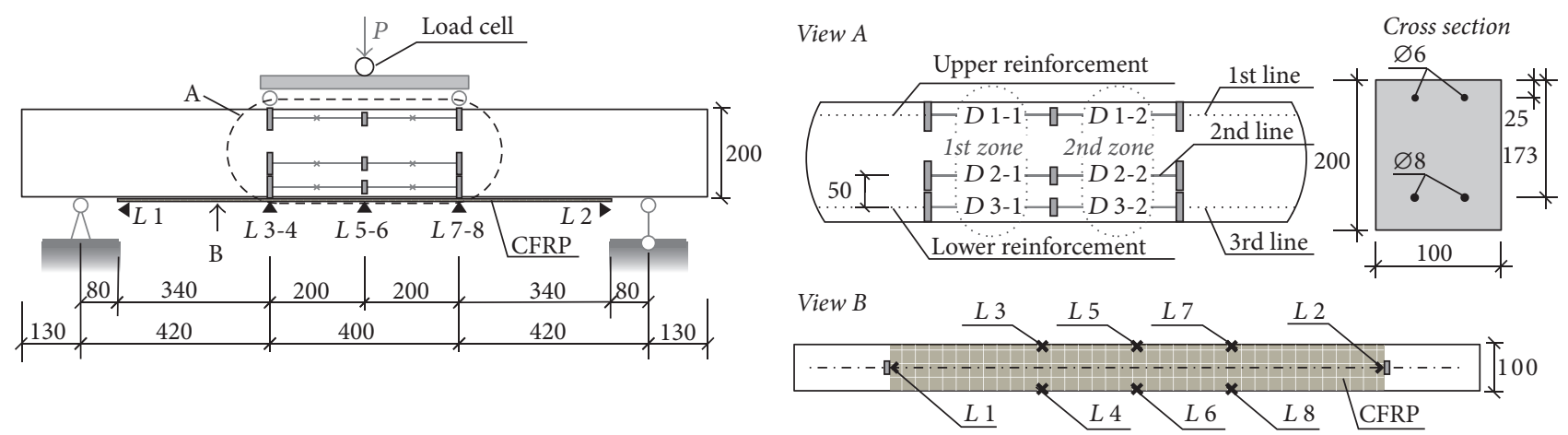

Figure 3: Beam test setup.

TABLE 2: Main parameters of the steel fibres.

\begin{tabular}{lccc}
\hline Supplier & Length, mm & Diameter, mm & $\begin{array}{c}\text { Tensile } \\
\text { strength, } \\
\mathrm{MPa}\end{array}$ \\
\hline Dudoloc & $55 \pm 0.5$ & 1 & 1020 \\
Mechel NeMunas & $50 \pm 2$ & $1 \pm 0.1$ & $1000-1300$ \\
\hline
\end{tabular}

of the first group (B1-nm-C1-F0, B7-nm-Ref-F0, and B8-C1$F 0$ ) were made of ordinary concrete, whereas the beams of the second group (B2-nm-C1-F0.8, B3-Ref-F0.8, B4-Ref-F0.8, B5C1-F0.8, and B6-C1-F0.8) had a $0.8 \%$ of steel fibres. The main parameters of the experimental beams are listed in Table 1 and Figure 3.

The beams with a notation " $n m$ " referring to "nonmetallic" had $2 \times \varnothing 8 \mathrm{~mm}$ bottom reinforcement bars made of glass fibre reinforced polymer (GFRP) and $2 \times \varnothing 6 \mathrm{~mm}$ steel bars (S500) as the top reinforcement. The rest of the beams were reinforced with $2 \times \varnothing 8 \mathrm{~mm}$ and $2 \times \varnothing 6 \mathrm{~mm}$ deformed steel bars in the tensile and compressive zones, respectively.

The beams were tested under a four-point bending scheme with $420 \mathrm{~mm}$ shear spans as shown in Figure 3. The specimens were loaded using a $5000 \mathrm{kN}$ hydraulic jack in a rigid testing frame. The loading rate was $0.2 \mathrm{~mm} / \mathrm{min}$. As shown in Figure 3, three continuous LVDT lines were located at different heights. The two outer LVDT lines were placed along the top and bottom reinforcement, whereas the inner line was located $50 \mathrm{~mm}$ off the bottom one. The vertical displacements in pure bending zone were measured by the LVDT ( $L 3-8$, Figure 3 ). Slip of the CFRP sheets in relation to the concrete surface has been recorded using LVDT (L 1-2). A zoomed view of this zone is presented in Figure 4. A load cell was used to measure the applied load. ALMEMO 2890-9 data logger was used to collect the recordings from LVDT and the load cell. Development of the cracks was observed using the optical microscope. After the tests, the final crack patterns were fixed and marked.

\section{Test Results}

3.1. Tie Test. The load-strain diagrams of the ties are presented in Figure 5. As can be observed from Figure 5(a),

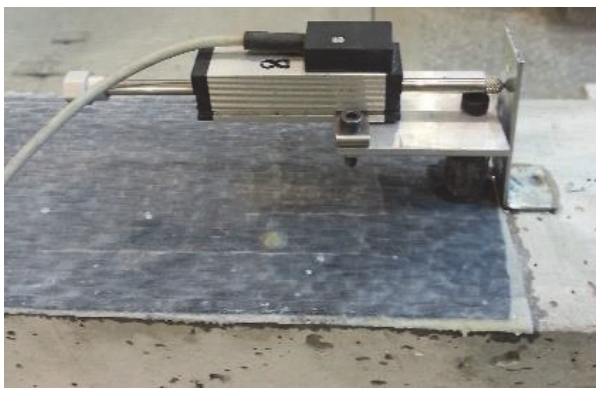

Figure 4: Slip measurement of the CFRP sheet.

the load bearing capacity of the reference specimen (T3$R e f-F 0$ ) was to a significant extent higher than the ultimate capacity obtained for the strengthened tie (T1-C3-F0) due to the splitting failure of the concrete at the end of the latter specimen (Figure 6(a)). In contrast to this, the tie T2C1-F0.6 made of steel fibre reinforced concrete (SFRC) and externally bonded with CFRP was loaded up to the yielding of the bar without any failure of the concrete (Figure 6(b)). This indicates an ability of the fibres to ensure the structural integrity of the externally bonded composite which in turn leads to a significantly increased number of cracks (Figure 7) of reduced opening width.

It is worth mentioning that different axial stiffness is characteristic of the external sheets made using one and three layers of CFRP. Notwithstanding this difference, both externally reinforced ties ( $\mathrm{T} 1-\mathrm{C} 3-\mathrm{FO}$ and $\mathrm{T} 2-\mathrm{Cl}-\mathrm{FO} .6$ ) demonstrated an almost identical load-deformation behaviour until the failure of the plain concrete prism (Figure 5). This is a consequence of the testing layout when the load is applied directly to the bar reinforcement while the surrounding concrete transfers deformations to the external sheets. Thus, the effect of stiffness of the external sheets on the total stiffness of the tie becomes marginal. Gribniak in a coauthorship [28] discussed this effect in detail. The most important outcome of this test programme, therefore, is that the addition of fibres improves the failure character of the externally bonded ties by preventing the brittle failure of the concrete. The load bearing capacity of the SFRC tie was increased by approximately $70 \%$. 


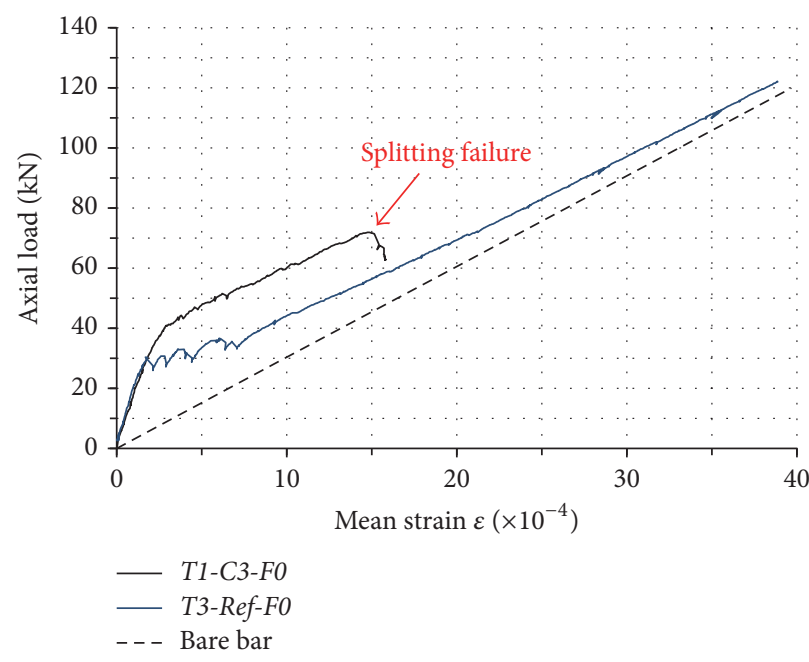

(a)

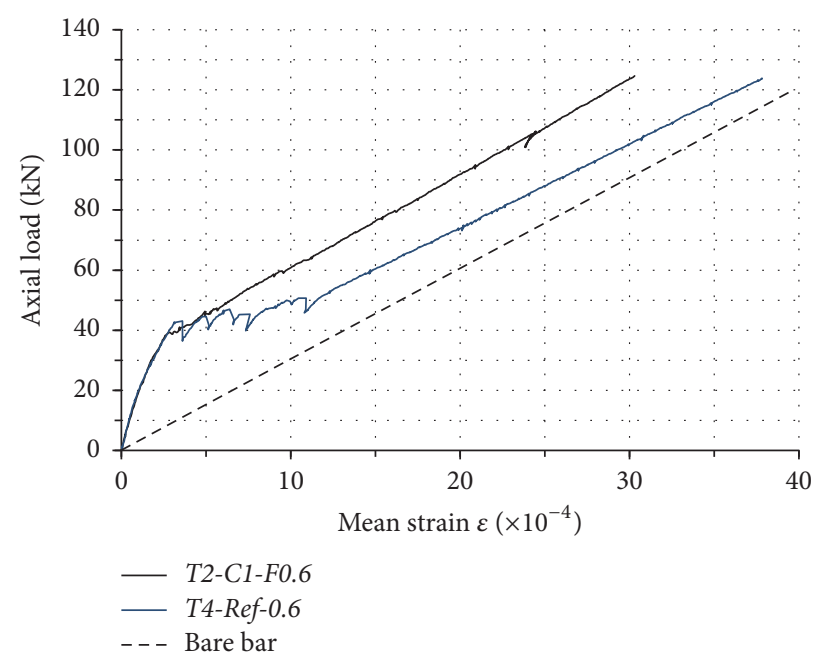

(b)

FIGURE 5: Load-strain diagrams of RC ties made of ordinary concrete (a) and SFRC (b).

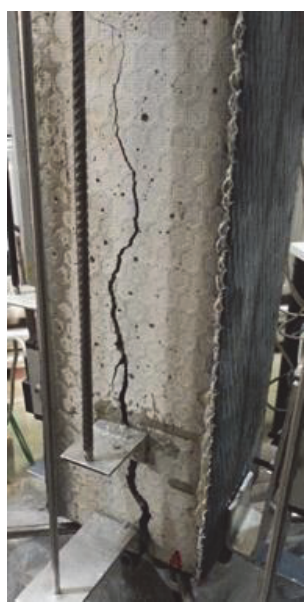

(a)
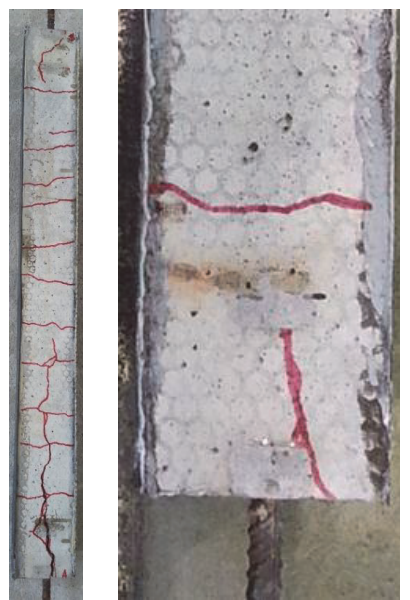

(b)
FIGURE 6: Failure character of RC tensile specimens: splitting of the ordinary concrete prism in the tie T1-C3-FO (a); absence of failure of the tie T2-C1-F0.6 made of SFRC (b).

3.2. Beam Test. Deflection measurement errors might have a significant influence on the assessment of flexural stiffness of composite elements [27]. At the elastic stage, the error in gross deflection measurement is almost linear up to the firstcrack. It can be eliminated by accounting for the elastic deformations of the supports. In the postcracking regime, the errors are related to the load bearing capacity of the specimen and they increase with the reduction of beam dimensions. The latter effect is mainly related to the distribution (and number) of the flexural cracks. Previous research by the authors [29] revealed that the curvature assessments (averaged throughout the pure bending zone) can be considered as an efficient parameter for a comparative analysis of composite beams with different flexural rigidity.
Following the methodology presented in [30, 31], moment-curvature diagrams of the beams have been derived using the recordings of deflections and concrete surface strains measured within the pure bending zone (Figure 3). Assuming a circular arc shape of deflection curve along the pure bending zone, the average curvature can be obtained from the deflection readings as follows:

$$
\begin{aligned}
\kappa=\frac{2 \cdot \delta}{\left(l_{b} / 2\right)^{2}+\delta^{2}}=\frac{8 \cdot \delta}{l_{b}^{2}+4 \cdot \delta^{2}} ; \\
\quad \delta=\frac{\delta_{5}+\delta_{6}}{2}-\frac{\delta_{3}+\delta_{4}+\delta_{7}+\delta_{8}}{4} .
\end{aligned}
$$

Here $\delta$ is the deflection in the pure bending zone; $\delta_{i}$ is the deflection obtained by the $i$ th $(i=3, \ldots, 8)$ linear variable differential transducer $L_{i}$ (Figure 3 ); $l_{b}$ is the length of the bending zone (in our case, it was equal to $400 \mathrm{~mm}$ ).

An alternative curvature assessment technique is based on the concrete strains averaged along each of the gauge lines shown in Figure 3. The averaged curvature is calculated as

$$
\kappa=\frac{1}{3} \sum_{l=2}^{3} \sum_{k=1}^{l-1} \frac{D_{k}-D_{l}}{h_{k l}} .
$$

Here $D_{k}$ and $D_{l}$ are the averaged strains along $k$ and $l$ lines (Figure 3), respectively; $h_{k l}$ is the distance between these lines.

Figure 8 shows the moment-curvature diagrams of the selected beams determined using both aforementioned methodologies. A good agreement is achieved between the diagrams obtained using the monitoring results of deflection and surface strains of the concrete. The previous studies $[29,30]$, however, revealed that the diagrams obtained using the surface strains can be considered as a robust (independent of measurement inaccuracies) experimental output for comparative analysis purposes. Consequently, the present analysis is based on the curvatures obtained from the average strains of the concrete. 

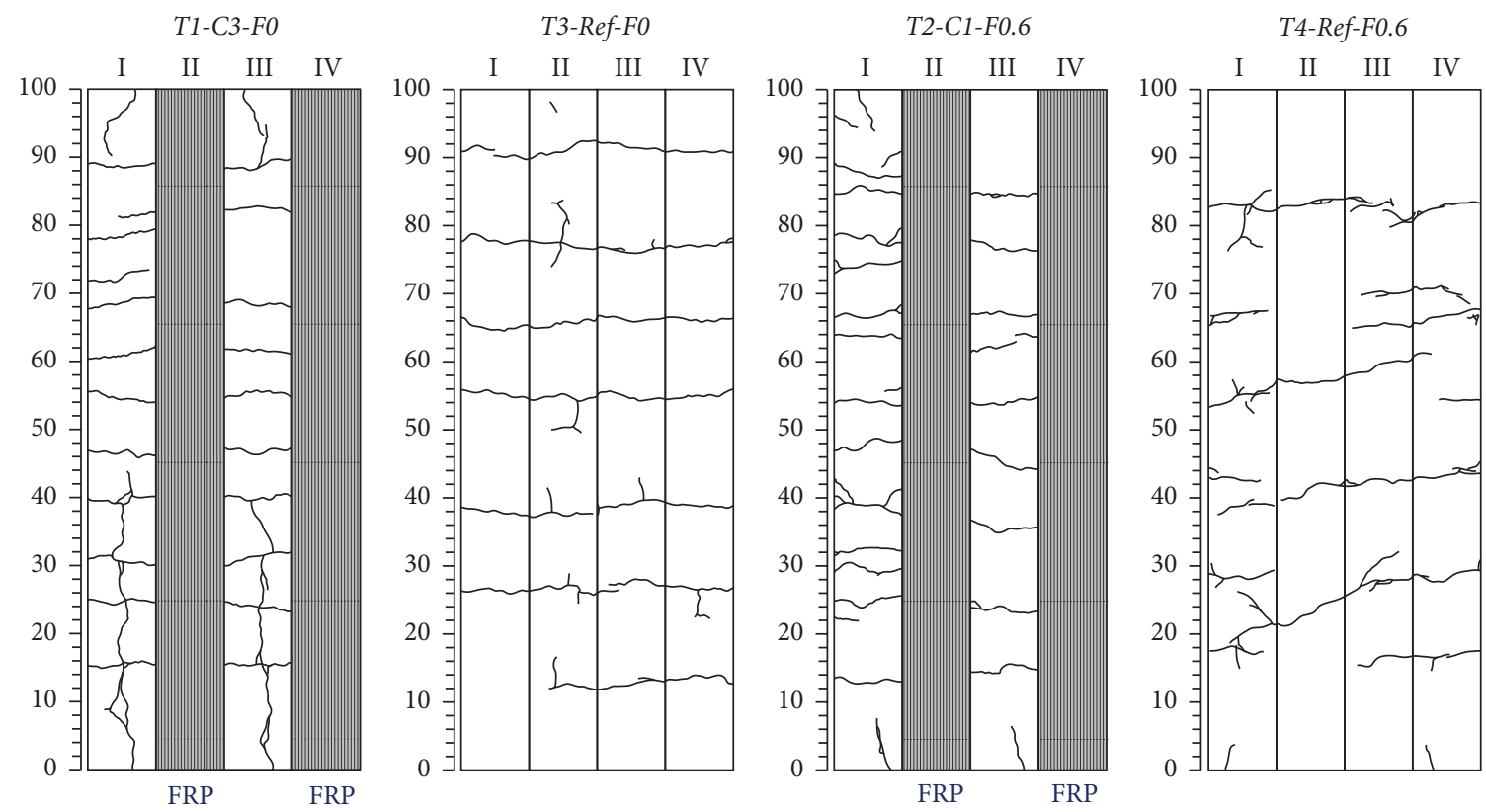

FIGURE 7: Crack pattern of the ties.

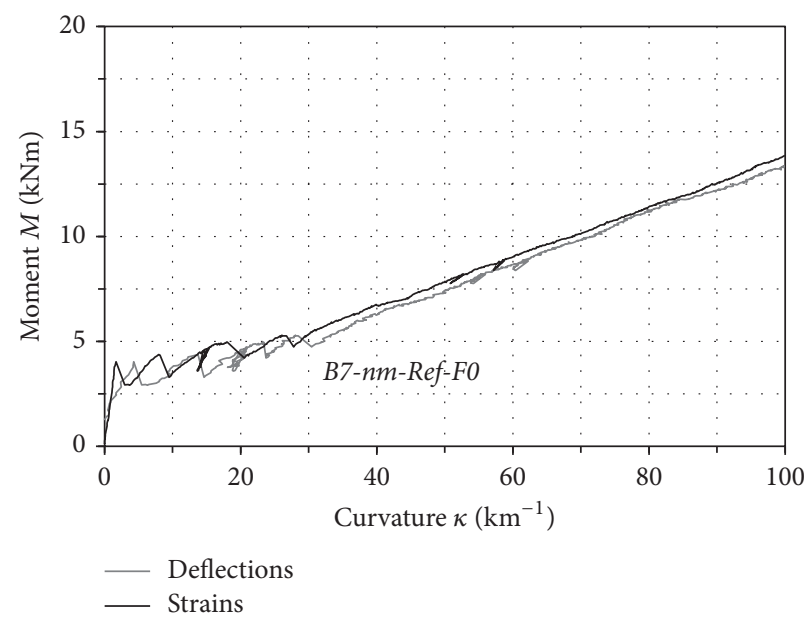

(a)

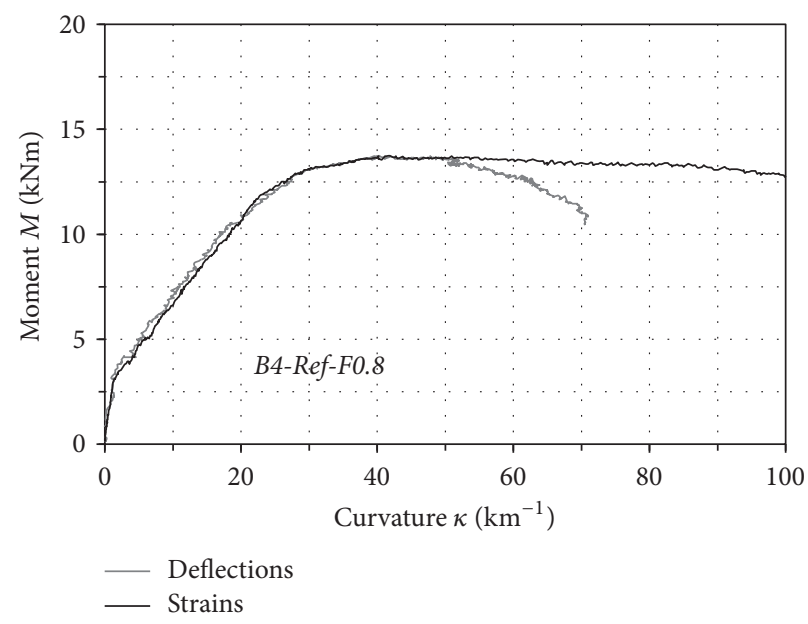

(b)

FIGURE 8: Moment-curvature diagrams of selected beams obtained using the monitoring results of surface strains and deflections.

The obtained moment-curvature diagrams are shown in Figure 9. As can be observed from Figure 9(a), the load bearing capacity of the beam B1-nm-C1-F0 with external CFRP sheet was even lower than for the reference one (B7$n m-R e f-F 0)$. The addition of steel fibres results in a noticeable increase of the ultimate load (compare B5-C1-F0.8 and B6C1-F0.8 to B8-C1-F0 in Figure 9). A good agreement of the results obtained for the twin specimens (B3-Ref-F0.8 and B4Ref-F0.8 as well as B5-C1-F0.8 and B6-C1-F0.8) indicates the consistence of the analytical procedure.

Final crack patterns of the beams are shown in Figure 10. In this figure, the specimens are presented in two groups by the type of the internal bar reinforcement. It should be pointed out that an increased number of cracks may be related to the additional fracture energy dissipation and, consequently, increase in stiffness. In the considered specimens, this occurs due to the ability of fibres and/or CFRP sheets to transfer tension stresses in a crack. This composite action is even more evident in combination with GFRP bar reinforcement.

The failure character is another important issue that must be analysed. In the specimens without steel fibres, the failure was due to splitting of the concrete cover at the level of the longitudinal reinforcement (Figure 11(a)), whereas debonding of the CFRP sheets at the interfaces between the concrete and the adhesive was characteristic of the beams made of SFRC (Figure 11(b)). Although the deformations and the load bearing capacity of the beams reinforced with GFRP bars were practically the same (Figures 9 and 12), the failure 


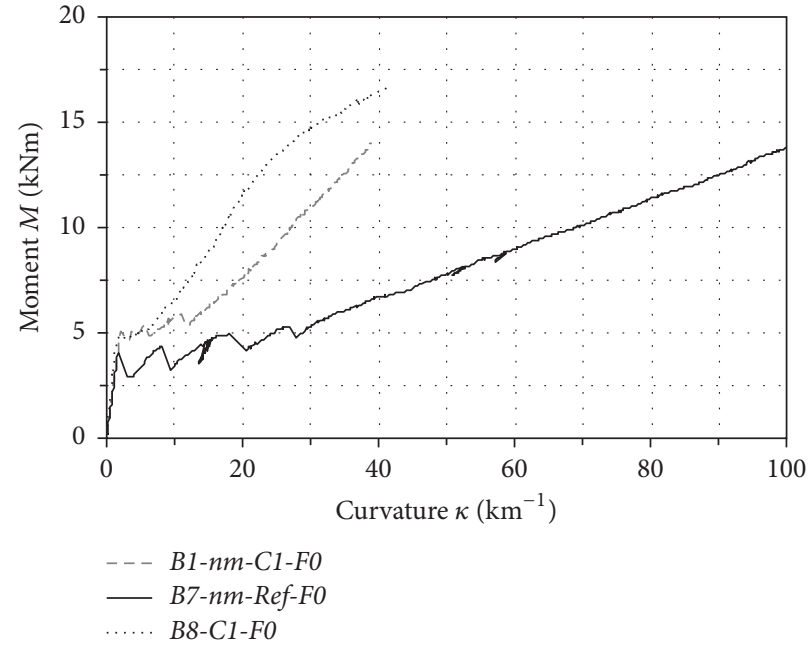

(a)

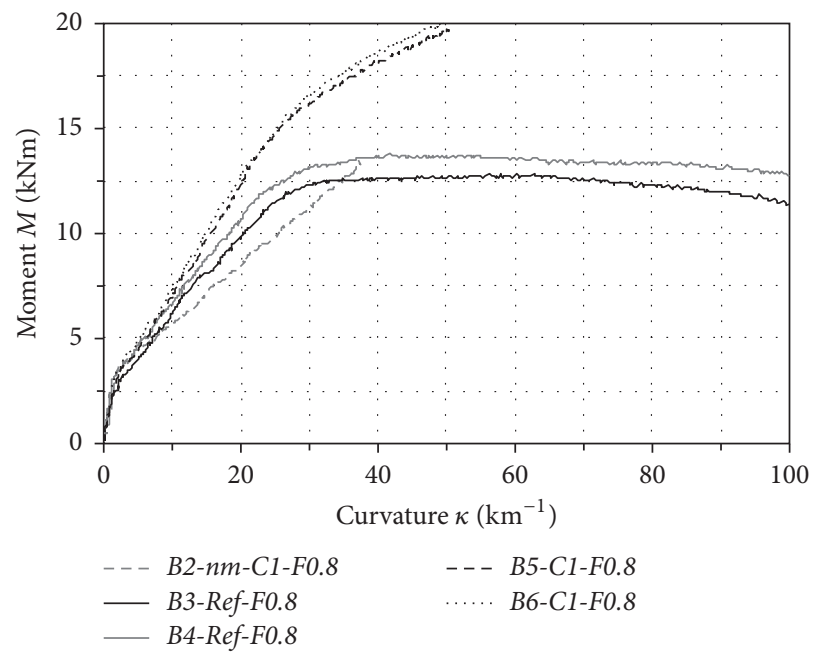

(b)

FIGURE 9: Moment-curvature diagrams of the beams made of ordinary concrete (a) and SFRC (b).

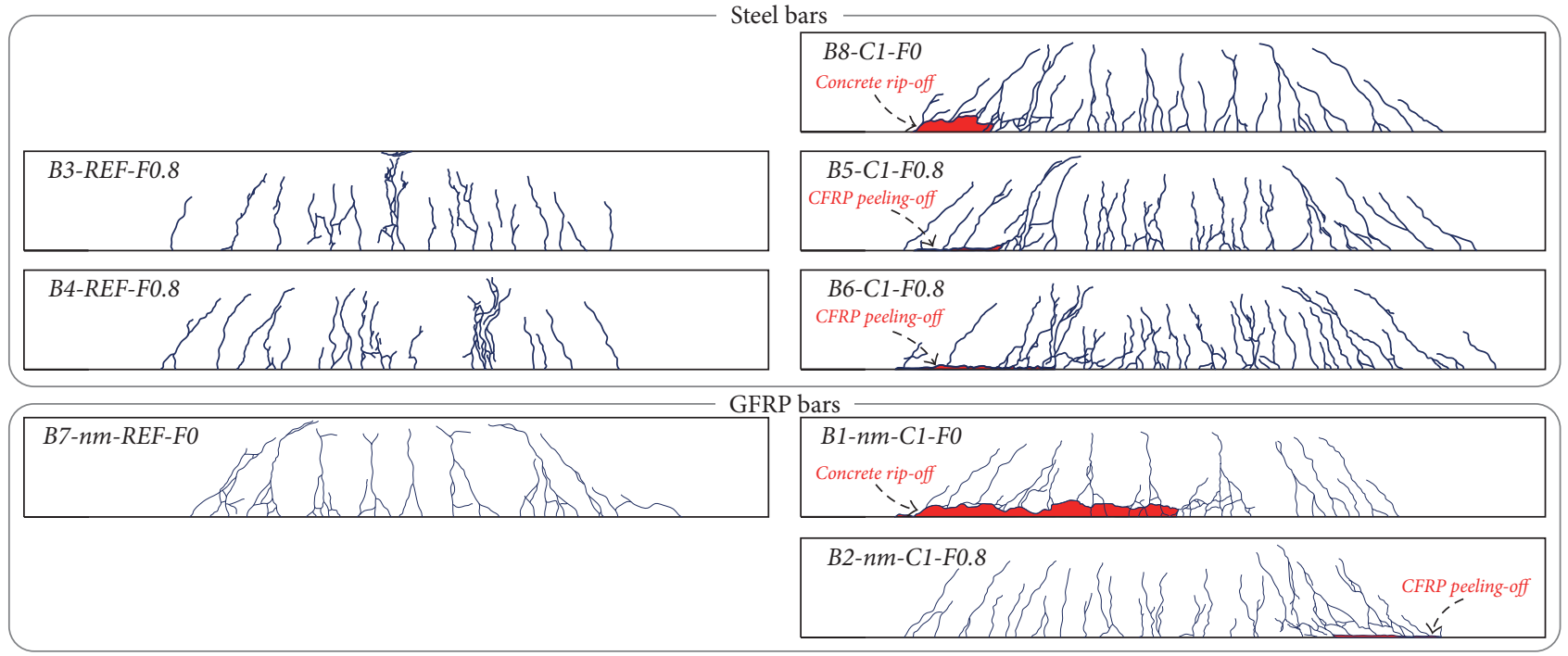

FIgURE 10: Final crack pattern of the beams.

character was completely different. As can be observed in Figure 10, the concrete rip-off was typical for the beam made of ordinary concrete (B1-nm-C1-FO), whereas fibre reinforcement transferred the failure from the concrete to the interface zone, thus resulting in the peeling-off of the FRP sheet (B2-nm-C1-F0.8). Another important aspect is that the compressive strength of ordinary concrete and SFRC was different (50.6 MPa and 31.6 MPa, respectively). The observed failure indicates that the application of the fibres is more effective than the increase of the concrete strength at ensuring the structural integrity of the beams. Considering the crack patterns and moment-curvature diagrams shown in Figures 10 and 12 , two main observations can be made:

(i) Application of fibres in the specimens reinforced with steel bars increased the load bearing capacity by altering the failure character. Comparing the crack patterns of the strengthened elements, an increase in the number of cracks is not evident.

(ii) The fibres affect both the load bearing capacity and the stiffness of the beams reinforced with GFRP bars. Despite the significant difference in strength of the concrete (Table 1), the ultimate load was observed to be practically identical (Figure 12(b)). However, the number of cracks has evidently increased (comparing the beams B1-nm-C1-FO and B2-nm-C1-F0.8, Figure 10). As was found by the authors [7], the increased number of cracks could be attributed to the difference in the relative internal-to-external flexural stiffness of the reinforcement that is equal to 2.6 and 0.87 , respectively, for steel and GFRP bars. 


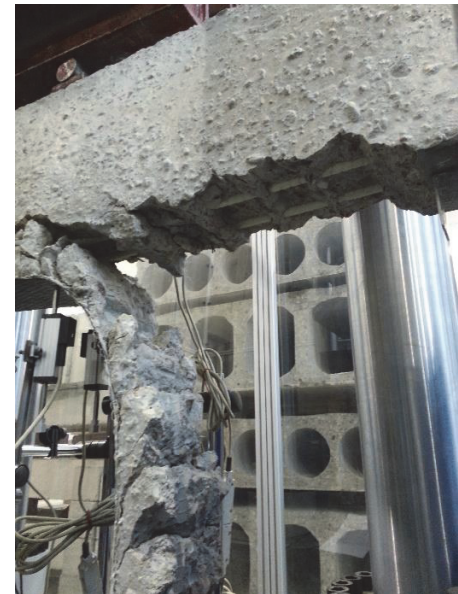

(a)

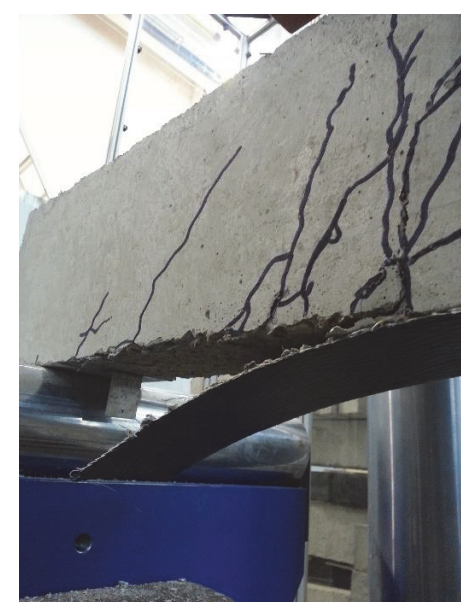

(b)

FIGURE 11: Failure character of RC beams: concrete rip-off of the beam (B1-nm-C1-F0) made of ordinary concrete (a); CFRP peeling-off of the beam (B6-C1-F0.8) made of SFRC (b).

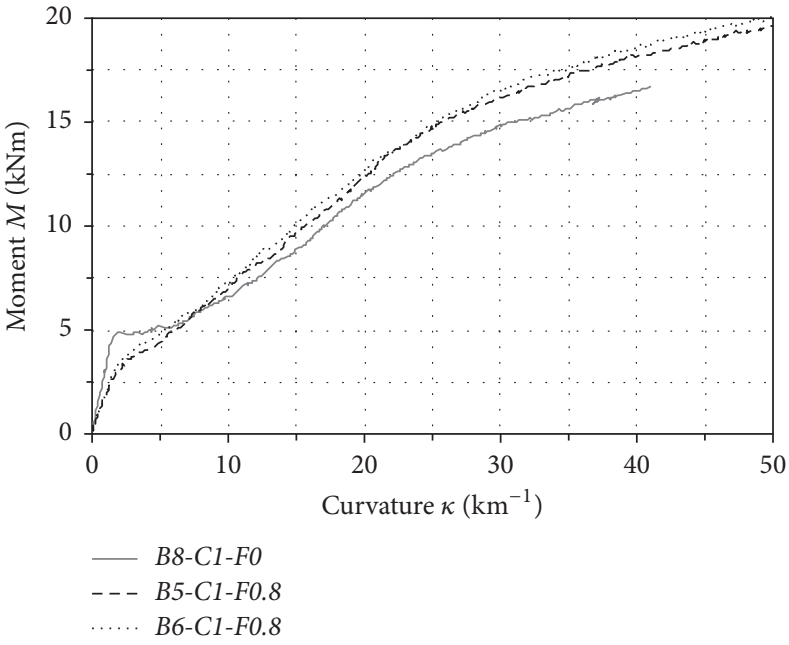

(a)

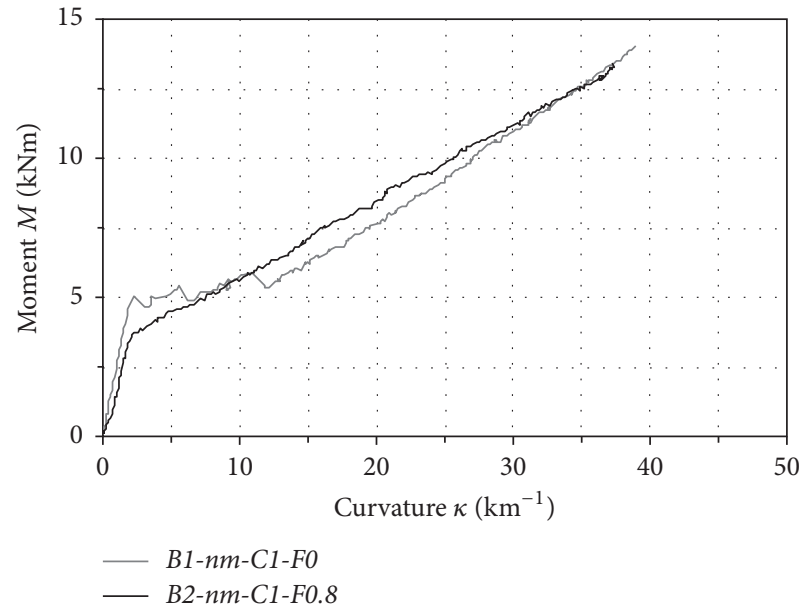

(b)

FIGURE 12: Moment-curvature diagrams of the beams reinforced with steel (a) and GFRP (b) bars.

\section{Conclusions}

The paper experimentally investigates the influence of steel fibres on the failure character of concrete elements bonded with external carbon fibre reinforced polymer (CFRP) sheets. The deformation and cracking behaviour of concrete ties and beams reinforced with steel or GFRP bars and externally bonded with CFRP sheets have been analysed. The experimental data of four ties and eight beams are presented. The study reveals the following:

(1) The addition of fibres improves the failure character of the specimens reinforced with CFRP sheets by preventing brittle failure of the concrete.

(2) The fibres have increased the load-carrying capacity of the externally bonded ties by approximately $70 \%$. Similar results were obtained for the beams reinforced with steels bars: the bearing capacity was increased by almost 25\%.

(3) The increased number of cracks may be related to the higher flexural stiffness due to the ability of fibres and/or CFRP sheets to transfer tension stresses at a crack. This composite action is even more evident in combination with GFRP bar reinforcement.

(4) Due to the relatively small amount of test specimens, further research is needed to quantify the effectiveness of fibres. The means of preventing the debonding effect should also be explored.

\section{Competing Interests}

The authors declare that the grant mentioned in the Acknowledgments or any other scholarships and funding do not lead 
to any conflict of interests. Additionally, the authors declare that there is no conflict of interests regarding the publication of this manuscript.

\section{Acknowledgments}

The authors gratefully acknowledge the financial support provided by the Research Council of Lithuania (Research Project MIP-050/2014).

\section{References}

[1] L.-P. Guo, A. Carpinteri, R. Roncella, A. Spagnoli, W. Sun, and S. Vantadori, "Fatigue damage of high performance concrete through a 2D mesoscopic lattice model," Computational Materials Science, vol. 44, no. 4, pp. 1098-1106, 2009.

[2] L. Guo, W. Zhang, W. Sun, B. Chen, and Y. Liu, "High-temperature performance and multiscale damage mechanisms of hollow cellulose fiber-reinforced concrete," Advances in Materials Science and Engineering, vol. 2016, Article ID 2503780, 14 pages, 2016.

[3] B.-I. Bae, H.-K. Choi, and C.-S. Choi, "Flexural strength evaluation of reinforced concrete members with ultra high performance concrete," Advances in Materials Science and Engineering, vol. 2016, Article ID 2815247, 10 pages, 2016.

[4] J. Song and S. Liu, "Properties of reactive powder concrete and its application in highway bridge," Advances in Materials Science and Engineering, vol. 2016, Article ID 5460241, 7 pages, 2016.

[5] E. Gudonis, E. Timinskas, V. Gribniak, G. Kaklauskas, A. K. Arnautov, and V. Tamulènas, "FRP reinforcement for concrete structures: state-of-the-art review of application and design," Engineering Structures and Technologies, vol. 5, no. 4, pp. 147158, 2013.

[6] A. Sokolov, G. Kaklauskas, R. Jakubovskis et al., "Experimental investigation of tension stiffening in RC ties," Advances in Materials Science and Engineering, vol. 2016, Article ID 6965932, 8 pages, 2016.

[7] V. Gribniak, A. K. Arnautov, G. Kaklauskas, V. Tamulenas, E. Timinskas, and A. Sokolov, "Investigation on application of basalt materials as reinforcement for flexural elements of concrete bridges," The Baltic Journal of Road and Bridge Engineering, vol. 10, no. 3, pp. 201-206, 2015.

[8] D. M. Nguyen, T. K. Chan, and H. K. Cheong, "Brittle failure and bond development length of CFRP-concrete beams," Journal of Composites for Construction, vol. 5, no. 1, pp. 12-17, 2001.

[9] O. Buyukozturk, O. Gunes, and E. Karaca, "Progress on understanding debonding problems in reinforced concrete and steel members strengthened using FRP composites," Construction and Building Materials, vol. 18, no. 1, pp. 9-19, 2004.

[10] J. Sim, C. Park, and D. Y. Moon, "Characteristics of basalt fiber as a strengthening material for concrete structures," Composites Part B: Engineering, vol. 36, no. 6-7, pp. 504-512, 2005.

[11] I. A. Sharaky, L. Torres, and H. E. M. Sallam, "Experimental and analytical investigation into the flexural performance of RC beams with partially and fully bonded NSM FRP bars/strips," Composite Structures, vol. 122, pp. 113-126, 2015.

[12] G. Tumialan, P. Serra, A. Nanni, and A. Belarbi, "Concrete cover delamination in reinforced concrete beams strengthened with carbon fiber reinforced polymer sheets," ACI Special Publication, vol. 188, pp. 725-736, 1999.
[13] B. Gao, C. K. Y. Leung, and J.-K. Kim, "Failure diagrams of FRP strengthened RC beams," Composite Structures, vol. 77, no. 4, pp. 493-508, 2007.

[14] J. Yin and Z. S. Wu, "Structural performances of short steel-fiber reinforced concrete beams with externally bonded FRP sheets," Construction and Building Materials, vol. 17, no. 6-7, pp. 463470, 2003.

[15] L. Li, Y. Guo, and F. Liu, "Test analysis for FRC beams strengthened with externally bonded FRP sheets," Construction and Building Materials, vol. 22, no. 3, pp. 315-323, 2008.

[16] D. Hansel and P. Guirguis, "Steel-fiber-reinforced shotcrete for tunnel linings: the state of the art : rose," International Journal of Rock Mechanics and Mining Sciences \& Geomechanics Abstracts, vol. 24, no. 2, 66 pages, 1987.

[17] G. Groli and A. P. Caldentey, "Improving cracking behaviour with Recycled Steel Fibres, targeting specific applications. Analysis according to MC2010," Structural Concrete, 2016.

[18] P. J. D. Mendes, J. A. O. Barros, J. Sena-Cruz, and M. Teheri, "Influence of fatigue and aggressive exposure on GFRP girder to SFRSCC deck all-adhesive connection," Composite Structures, vol. 110, no. 1, pp. 152-162, 2014.

[19] F.-Y. Yeh, K.-C. Chang, Y.-C. Sung, H.-H. Hung, and C.-C. Chou, "A novel composite bridge for emergency disaster relief: concept and verification," Composite Structures, vol. 127, pp. 199-210, 2015.

[20] L. J. Sánchez-Aparicio, L. F. Ramos, J. Sena-Cruz, J. O. Barros, and B. Riveiro, "Experimental and numerical approaches for structural assessment in new footbridge designs (SFRSCCGFPR hybrid structure)," Composite Structures, vol. 134, pp. 95105, 2015.

[21] H. Aoude, M. Belghiti, W. D. Cook, and D. Mitchell, "Response of steel fiber-reinforced concrete beams with and without stirrups," ACI Structural Journal, vol. 109, no. 3, pp. 359-367, 2012.

[22] N. Spinella, "Shear strength of full-scale steel fibre-reinforced concrete beams without stirrups," Computers and Concrete, vol. 11, no. 5, pp. 365-382, 2013.

[23] J. R. Deluce and F. J. Vecchio, "Cracking behavior of steel fiberreinforced concrete members containing conventional reinforcement," ACI Structural Journal, vol. 110, no. 3, pp. 481-490, 2013.

[24] G. Arslan, "Shear strength of Steel Fiber Reinforced Concrete (SFRC) slender beams," KSCE Journal of Civil Engineering, vol. 18, no. 2, pp. 587-594, 2014.

[25] J. R. Deluce, S.-C. Lee, and F. J. Vecchio, "Crack model for steel fiber-reinforced concrete members containing conventional reinforcement," ACI Structural Journal, vol. 111, no. 1, pp. 93-102, 2014.

[26] P. Bernardi, E. Michelini, F. Minelli, and G. Tiberti, "Experimental and numerical study on cracking process in RC and R/FRC ties," Materials and Structures/Materiaux et Constructions, vol. 49, no. 1-2, pp. 261-277, 2016.

[27] V. S. Gopalaratnam and R. Gettu, "On the characterization of flexural toughness in fiber reinforced concretes," Cement and Concrete Composites, vol. 17, no. 3, pp. 239-254, 1995.

[28] V. Gribniak, A. K. Arnautov, G. Kaklauskas, R. Jakstaite, V. Tamulenas, and E. Gudonis, "Deformation analysis of RC ties externally strengthened with FRP sheets," Mechanics of Composite Materials, vol. 50, no. 5, pp. 669-676, 2014.

[29] V. Gribniak, G. Kaklauskas, L. Torres, A. Daniunas, E. Timinskas, and E. Gudonis, "Comparative analysis of deformations and tension-stiffening in concrete beams reinforced with GFRP 
or steel bars and fibers," Composites Part B: Engineering, vol. 50, pp. 158-170, 2013.

[30] V. Gribniak, G. Kaklauskas, and D. Bacinskas, "Experimental investigation of shrinkage influence on tension stiffening of RC beams," in Proceedings of the 8th International Conference: Creep, Shrinkage and Durability of Concrete and Concrete Structures (ConCreep '09), R. Sato, K. Maekawa, T. Tanabe, K. Sakata, H. Nakamura, and H. Mihashi, Eds., pp. 571-577, Taylor \& Francis, Ise-Shima, Japan, 2009.

[31] V. Gribniak, V. Cervenka, and G. Kaklauskas, "Deflection prediction of reinforced concrete beams by design codes and computer simulation," Engineering Structures, vol. 56, pp. 2175-2186, 2013. 

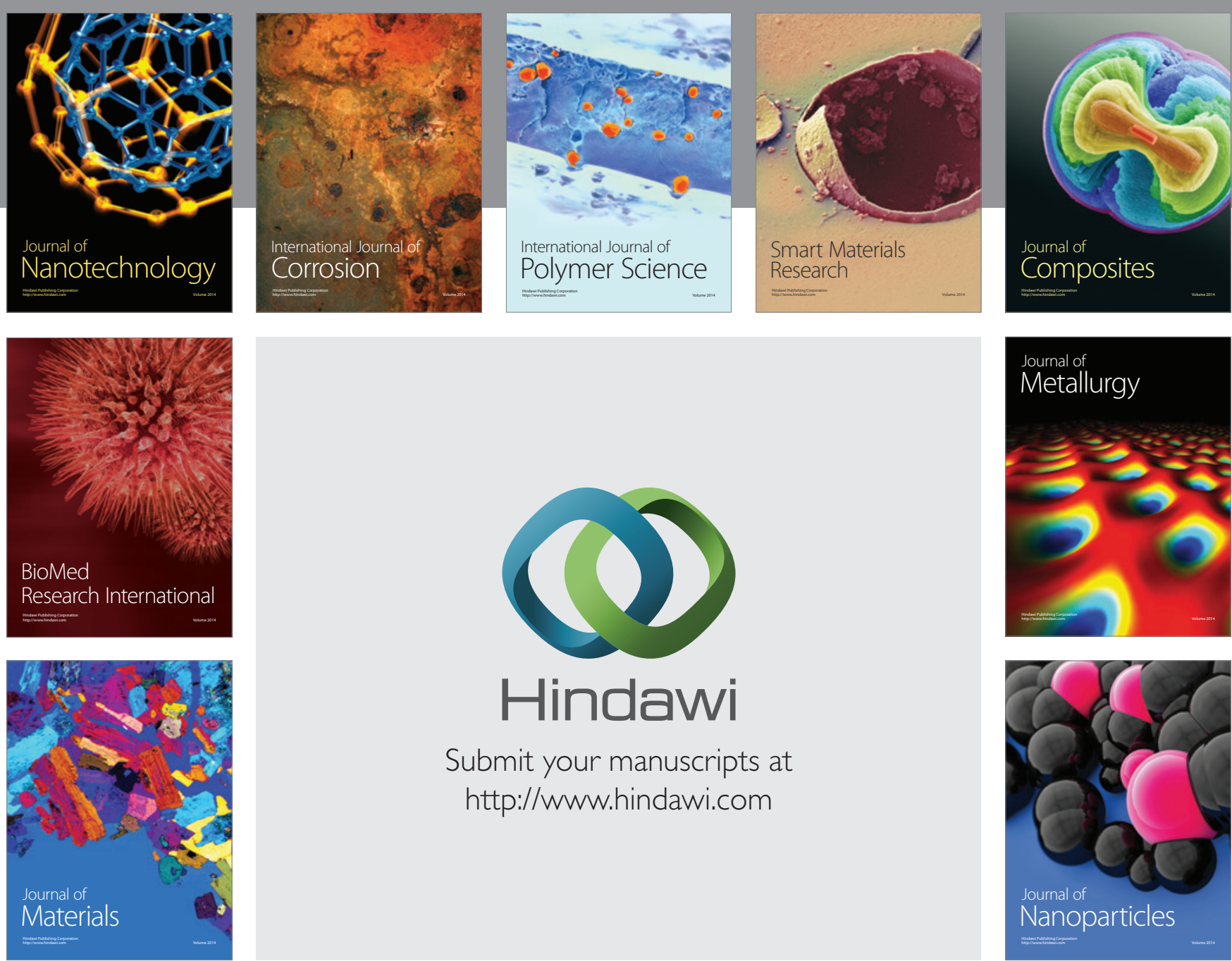

\section{Hindawi}

Submit your manuscripts at

http://www.hindawi.com

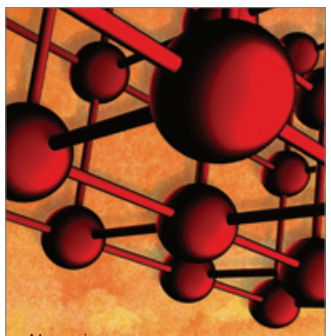

Materials Science and Engineering
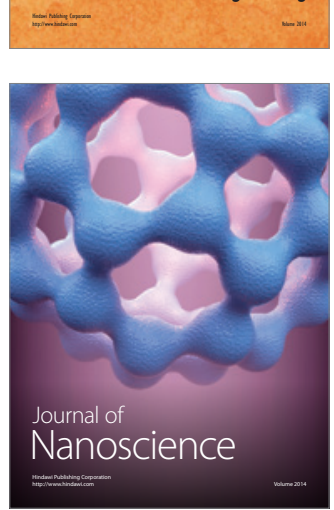
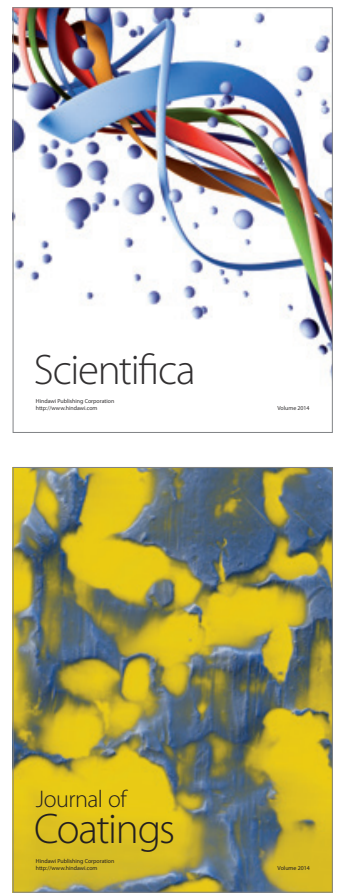
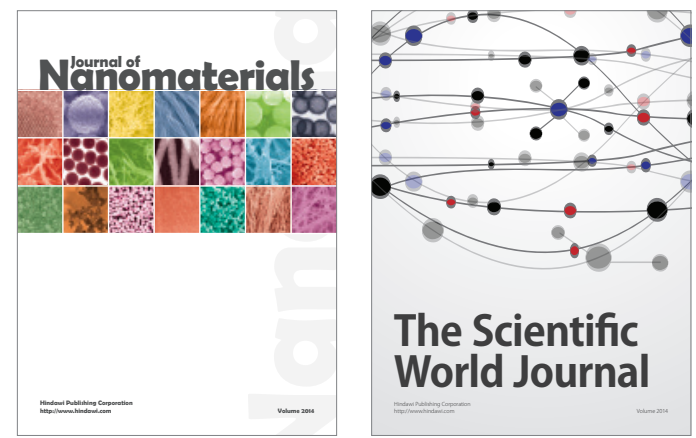

The Scientific World Journal
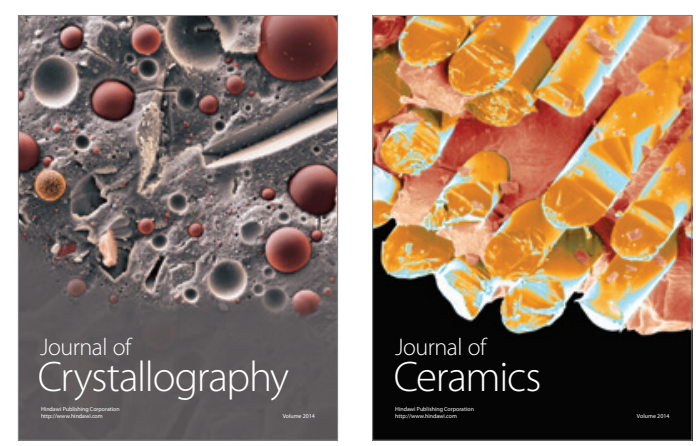
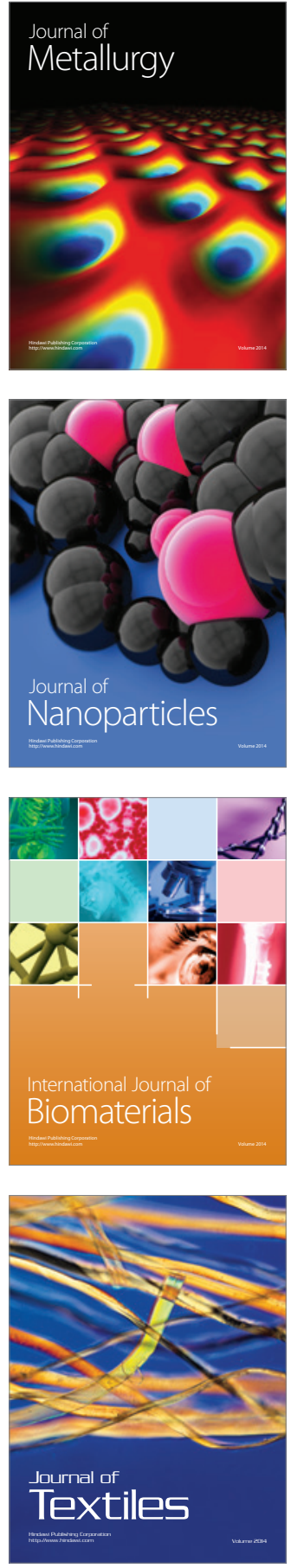